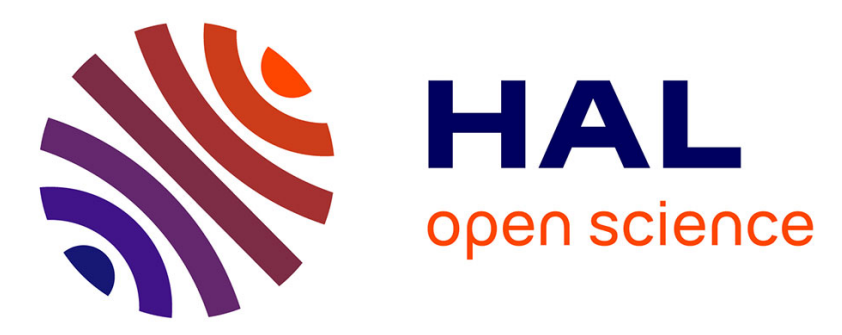

\title{
Chemical diversity and spatial variability in myriad lakes in Nhecolândia in the Pantanal wetlands of Brazil
}

Sonia Furian, Elisângela Rosemeri Curti Martins, Tatiana Mascari Parizotto, Ary Tavares Rezende-Filho, Reynaldo Luiz Victoria, Laurent Barbiero

\section{- To cite this version:}

Sonia Furian, Elisângela Rosemeri Curti Martins, Tatiana Mascari Parizotto, Ary Tavares RezendeFilho, Reynaldo Luiz Victoria, et al.. Chemical diversity and spatial variability in myriad lakes in Nhecolândia in the Pantanal wetlands of Brazil. Limnology and Oceanography Bulletin, 2013, 58 (6), pp.2249-2261. hal-02043233

\section{HAL Id: hal-02043233 https://hal.science/hal-02043233}

Submitted on 20 Feb 2019

HAL is a multi-disciplinary open access archive for the deposit and dissemination of scientific research documents, whether they are published or not. The documents may come from teaching and research institutions in France or abroad, or from public or private research centers.
L'archive ouverte pluridisciplinaire HAL, est destinée au dépôt et à la diffusion de documents scientifiques de niveau recherche, publiés ou non, émanant des établissements d'enseignement et de recherche français ou étrangers, des laboratoires publics ou privés. 


\section{Chemical diversity and spatial variability in myriad lakes in Nhecolândia in the Pantanal wetlands of Brazil}

Sônia Furian, ${ }^{1, *}$ Elisângela Rosemeri Curti Martins, ${ }^{1}$ Tatiana Mascari Parizotto, ${ }^{1}$ Ary Tavares Rezende-Filho, ${ }^{2}$ Reynaldo Luiz Victoria, ${ }^{3}$ Laurent Barbiero ${ }^{3,4}$

${ }^{1}$ Departamento de Geografia, Universidade de São Paulo, São Paulo, Brazil

${ }^{2}$ Departamento de Geografia, Unversidade Federal do Mato Grosso do Sul, Campus de Nova Andradina, Nova Andradina, Brazil

${ }^{3}$ Centro de Energia Nuclear na Agricultura, Universidade de São Paulo, Piracicaba, Brazil

${ }^{4}$ Institut de Recherche pour le Développement, Géoscience Environnement Toulouse, Université de Toulouse, Toulouse, France

*Corresponding author: furian@usp.br

Running head : Pantanal shallow lakes functioning

\section{Acknowledgements}

We thank A. Ayres Montebelo for performing chemical analysis and Embiara and Centenario farms for providing access to the sites. J. Hesson of AcademicEnglishSolutions.com revised the English.

This research was supported by grants allotted by Centro Nacional de Desenvolvimento Científico e Tecnológico (CNPq), Sao Paulo Research Foundation (FAPESP), and Coordenação de Aperfeiçoanamento de Pessoal de Nível Superior (CAPES) to E.R.C.Martins, T.M. Parizotto, and L. Barbiero. It was funded by FAPESP (2008/09086-7, 2008/58089-9, and 2011/12770-0), National Institute of Sciences of the Universe (INSU-Ec2co), and CNPq (405898/2012-6).

\section{Abstract}

Nearly 15,000 shallow, saline, or freshwater lakes and ponds coexist in close proximity in the Nhecolândia, a 24,000 $\mathrm{km}^{2}$ subregion of the Pantanal wetland in Brazil. This study aims to understand the origin of such diversity in surface water, which is a key aspect for the wetland services and biodiversity in the region. Both soil observations and water samples were collected at the regional or local scale and supplemented by previously published datasets. Statistical and geostatistical treatments were carried out, and completed by discrete water table monitoring. The results confirmed the absence of a regional pattern in surface water salinity, and the independence of electrical conductivity values, even for neighboring lakes. Despite great differences in chemical composition, all surface waters in the region belong to the same chemical family, corresponding to several concentration stages of the Taquari River water that supplies the region. The concentration stage depends on the hydrological functioning of each lake, which is itself controlled by the relative importance of low permeability soils as a barrier to movement of water into or out of the lakes through the sub surface. In this framework, oligosaline ponds, freshwater lakes, and saline lakes work as recharge-, flow through-, and discharge-wetlands, respectively. The salinity observed in some lakes results from an ongoing process of accumulation and evaporation under relatively humid climatic conditions and poor drainage. 


\section{Introduction}

Wetlands support enormous reservoirs of biodiversity, improve the quality of surface water, reduce flood risk associated with extreme rainfall and supply streams during drought (Fustec and Lefeuvre 2000; Mitsch and Gosselink 2007; Reddy and DeLaune 2008). Being fragile ecosystems, even minor alterations in wetlands may significantly affect the environment. The development of laws to protect wetlands generally involves understanding their hydro-biogeochemical functioning, and in recent years, considerable progress has been made in temperate and tropical zones, in developed or emerging countries (Jolly et al. 2008; Humphries et al. 2011; Tooth et al. in press).

Paradoxically, although the Pantanal wetland is recognized as the largest inland wetland in the world (Por 1995), little research has been done on this wetland. Recent studies have reported on fluvial geomorphology, seasonal inundation and biogeochemical cycling (Batsviken et al. 2010; Zani et al. 2012; Evans and Costa 2013), but few papers have focused on the functioning of its lakes (McGlue et al. 2011, 2012). The Pantanal wetland lies in the heart of South America and consists of a patchwork of subregions with highly contrasted hydrological, chemical or pedological features (Rezende-Filho et al. 2012). Plans for canalization of the Paraguay River, known as the ParaguayParana Hidrovia project, potentially place at risk the natural flood regime of broad areas within the Pantanal, but future human effect may vary according to the characteristics of each subregion. This aspect is a key concern for environmentalists (Hamilton 1999, 2002; Gottgens et al. 2001); consequently, this study aims to contribute to further understanding the natural functioning of one of the largest Pantanal subregions: Nhecolândia.

The Nhecolândia subregion is located along the southern half of the vast Taquari alluvial fan. Due to its environmental heterogeneity, this subregion exhibits the greatest diversity of wildlife species richness and abundance compared to the rest of the Pantanal (Evans and Costa 2013). A major feature of the environmental heterogeneity is the presence of a myriad of shallow saline, oligosaline and freshwater lakes coexisting on the landscape, sometimes at short distances from each other $(\sim 200 \mathrm{~m}$ ). The number of lakes was estimated to be from 12,000 to 17,500 (Oliveira et al. 2011) including 500 to 600 saline lakes.

When subjected to conditions in which potential evapotranspiration exceeds rainfall, wetlands typically undergo cycles of inundation and desiccation that result in transient groundwater-surface water interactions. As a consequence of variable inflow and water loss, such systems are often associated with localized to widespread surface and/or groundwater salinization (McCarthy et al. 1991; Jolly et al. 2008; Humphries et al. 2011). In Nhecolândia, the current climatic conditions are not clearly conducive to accumulating salts, or even to maintaining the high evaporation of water that could lead to the observed salinities. The processes that account for the range in salinities have yet to be determined, and therefore, the presence of salts has formerly been attributed to alternations of wet and arid phases during the late Pleistocene (Klammer 1982; Ab'Saber 1988).

Despite the obvious geochemical contrasts, previous studies carried out on a limited number of lakes $(n=25)$ have shown that saline and non-saline surface and groundwater collected in lower Nhecolândia belong to the same chemical family, and can result from each other simply by processes of concentration or dilution (Barbiero et al. 2002). Moreover, the chemical composition of surface waters is the result of evaporation of the Taquari River water at different concentration stages (Rezende-Filho et al. 2012). Therefore, the presence of salinity could be explained by differential hydrological functioning of each type of lake. The study of one saline lake located in the heart of Nhecolândia has shown that the hydrology of the lake is governed by the presence of a subsurface threshold consisting of soil horizons with low permeability. These horizons have a high sodium equivalent fraction on the soil complex and are cemented by amorphous silica (Barbiero et al. 2008). Such a functioning was shown to favor solute accumulation in the lake.

A wide range of salinity in the surface water of Nhecolândia controls many aspects of the biodiversity. Identifying whether the salinity of these lakes is inherent or an ongoing process has significant bearing on the sustainable management and environmental protection of the region. For example, a decrease in the number of saline lakes that are key habitats for large concentrations of wading birds and migratory species would directly affect the biodiversity (Evans and Costa, 2013). 
On the other hand, to determine the factors that control the salinity of the lakes leads to predicting how these lakes could react to human effect or climate change in terms of water resource, but also in terms of biogeochemical functioning and ecological interactions with the surrounding areas.

Here, we used both select local observations and regional datasets collected either in the field, or compiled from previously published research. The objectives of this study are: 1) to understand the processes that interacted to condition the functioning of the landscape, 2) to assess the chemical and spatial variability in surface water and the possible distribution patterns of this variability, and 3 ) to determine whether the hydrogeochemical functioning, which was described locally in a single lake (Barbiero et al. 2008), can be generalized to the other lakes in the region.

\section{Methods}

Site

Nhecolândia lies on the southern region of the vast Taquari alluvial fan, one of the largest alluvial fans in the world (Buehler et al. 2011; Zani et al. 2012). With a total surface area of about $24,000 \mathrm{~km}^{2}$, the region is delimited in the north by the Taquari River, in the south by the Negro River, in the west by a portion of the Paraguay River, and in the east by the Maracaju plateau, which corresponds to the south eastern edge of the Pantanal wetland. The region has relatively closed drainage with little connection to major fluvial systems, and an abundance of small, round or irregular shaped lakes and ponds (Pott and Pott 2011). River floods affect the hydrological regime of the closest lakes, but in Nhecolândia the hydrological regime of most of the lakes depends on the intensity of local rainfall (Sakamoto 1997). Most of the fluxes connecting the lakes are in the subsurface (Barbiero et al. 2002).

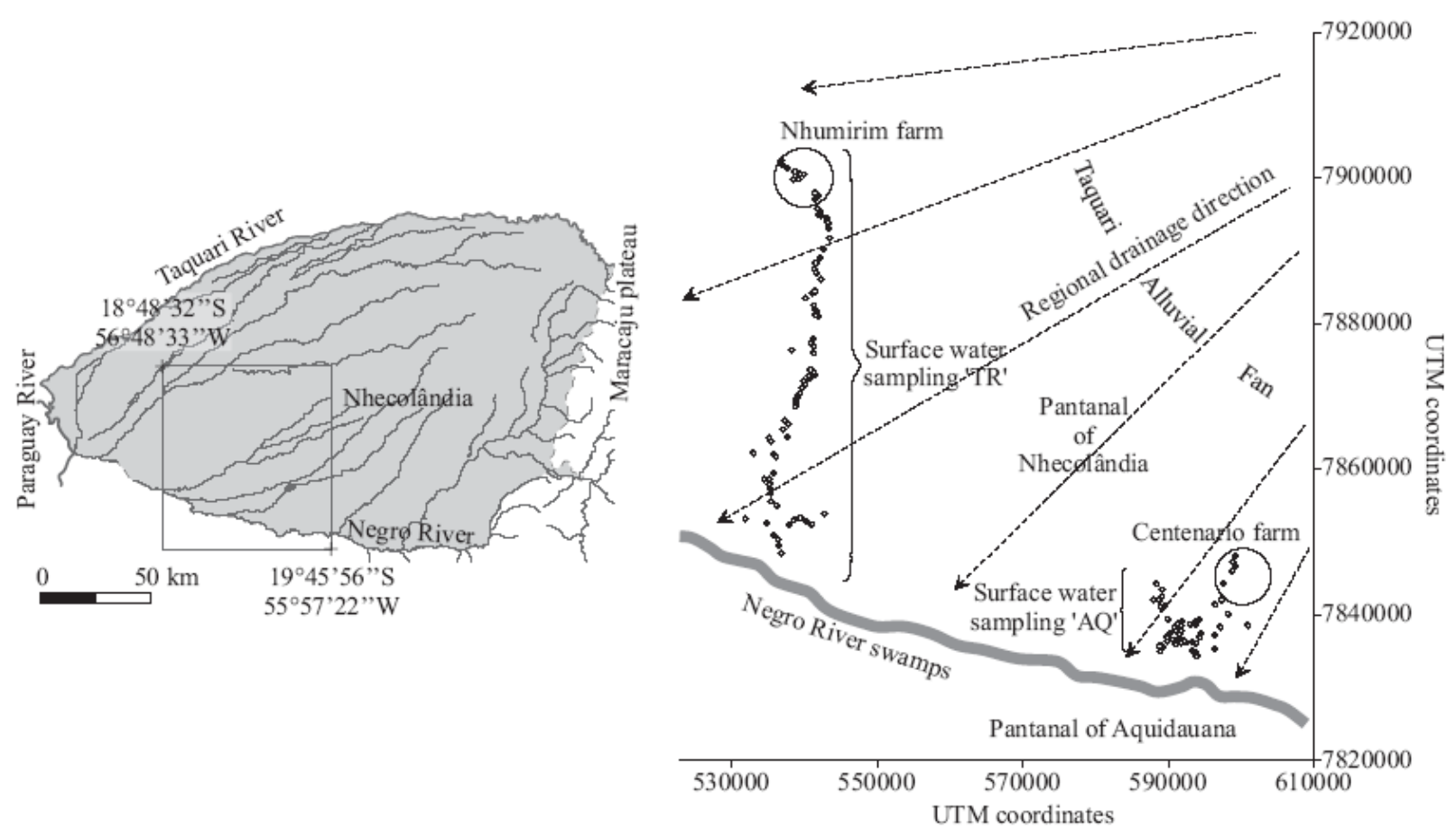

Figure 1 Location of sample sets AQ and TR in the Pantanal of Nhecolândia. The third sample set $\mathrm{NH}$ was collected near the Nhumirim farm.

Climate patterns in the Pantanal are controlled by the tropical latitude and seasonal migration of the Intertropical Convergence Zone (ITCZ). Nhecolândia has a tropical semi humid climate, classified as Tropical Humid with short dry season ('Aw' type) in the Köppen classification. The average summer air temperature is near $32^{\circ} \mathrm{C}$. The winter season is dry and colder with an average temperature of $21^{\circ} \mathrm{C}$, although frost can form during the occasional influx of southern polar air masses (IBGE 2003). The mean annual air temperature is $\sim 25^{\circ} \mathrm{C}$. Mean annual precipitation (P) is $\sim 1100 \mathrm{~mm}$, with a standard deviation above $30 \%$, and the annual evapotranspiration (ETP) is 
approximately $1400 \mathrm{~mm}$, giving a hydrological deficit of $\sim 300 \mathrm{~mm}$. Precipitation and ETP show a pronounced seasonal cycle, with most rainfall occurring from October to April and with excesses from November to March (Tarifa 1986; Alho et al. 1988). At the local level, the strong thermal contrast between saline lakes and surrounding forested area causes day-night alternating winds that enhance evaporation (Quenol et al. 2006).

Quaternary sediments cover the Pantanal floodplain. In Nhecolândia, these sediments arise from sandstone formations (mainly the Botucatu and Aquidauana Formations) that make up the Maracajú plateau (Assine and Soares 2004).

\section{Regional sampling}

The study is based on three datasets collected from surface waters in Nhecolândia (Fig. 1). The first sample set (AQ), which was collected in 2010, consists of 73 lakes and ponds located north of the city of Aquidauana. The second set (TR) consists of 74 sites collected in 2004 along a northsouth transect from the Brazilian Agricultural Research Corporation's (EMBRAPA) experimental farm (Nhumirím farm) to the margins of the Negro River. This second sample set was described in Rezende-Filho et al. (2012) and was chosen so as to intersect the regional drainage that is oriented east northeast - west southwest, therefore maximizing the variability. The first two datasets are georeferenced. A third, non-georeferenced dataset (NH) comes from Fernandes (2007) and consists of a total of 156 samples collected in 2002, 2003, and 2004 in the immediate vicinity of the Nhumirim farm. The $\mathrm{pH}$ and electrical conductivity were acquired in the field for all samples at about $30 \mathrm{~m}$ from the shoreline. Samples were taken in duplicate and at $10 \mathrm{~cm}$ below the surface by immersing sample bottles, then filtered using $0.45 \mu \mathrm{m}$ cellulose acetate filters.

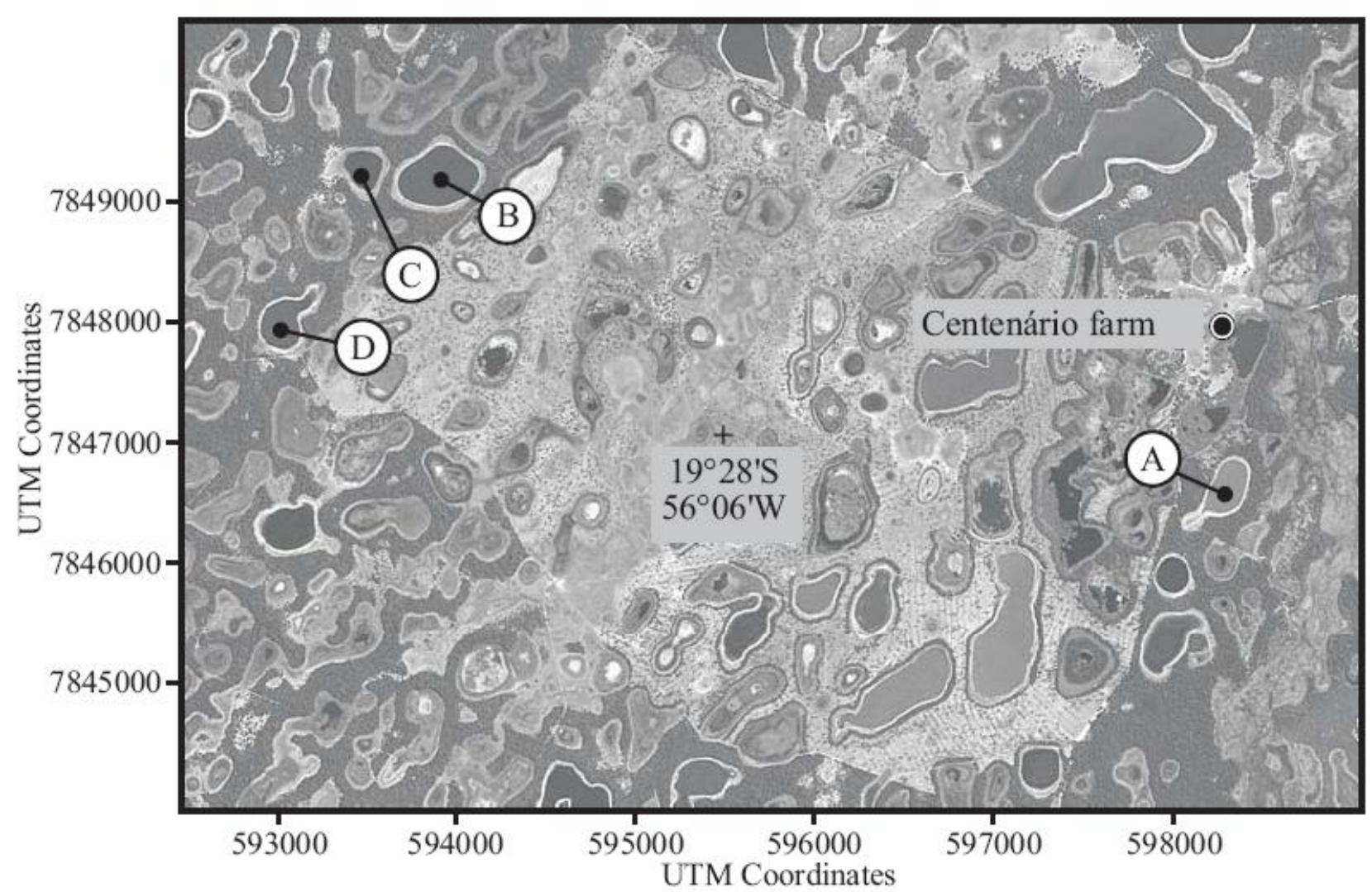

Figure 2 Location of the four saline lakes selected for electromagnetic induction survey of the soil cover in the Centenario farm.

\section{Lake chemistry}

For the sample sets AQ and TR, the waters were stored in a cool and dark place, then analyzed by ion chromatography for the anions $\left(\mathrm{Cl}^{-}, \mathrm{SO}_{4}{ }^{2-}, \mathrm{NO}_{3}{ }^{-}, \mathrm{F}^{-}\right)$, atomic absorption for the cations $\left(\mathrm{Ca}^{2+}\right.$, $\mathrm{Mg}^{2+}, \mathrm{Na}^{+}, \mathrm{K}^{+}$), and acid titration for alkalinity. A principal component analysis (PCA) was 
performed on these two datasets (147 samples) and based on the variables $\mathrm{Cl}^{-}, \mathrm{SO}_{4}{ }^{2-}$, Alkalinity (Alk), $\mathrm{Ca}^{2+}, \mathrm{Mg}^{2+}, \mathrm{Na}^{+}, \mathrm{K}^{+}$, Electrical Conductivity (EC) and $\mathrm{pH}$, in order to determine the main axis of variability in the surface water chemical composition. Using the georeferenced data sets AQ and TR, a geostatistical analysis was performed on the variable $\log _{10}(\mathrm{EC})$. Non-georeferenced data from $\mathrm{NH}$ were not included in the analysis.

Soil cover - local study

The organization of the soil cover has been studied on the perimeter of 4 saline lakes $(\mathrm{A}, \mathrm{B}, \mathrm{C}$, and D Fig. 2) and 1 oligosaline pond selected to cover a wide range of electrical conductivity (Table 1). Direct observations (auger holes and excavated pits) were combined with surveys by low frequency electromagnetic induction. Two devices were used: EM38-MK2 and EM31-MK2 (Geonics), which measure the apparent electrical conductivity (ECa) of soil from the surface in $\mathrm{mS} \mathrm{m}^{-1}$ (McNeill 1980). They are sensitive to soil texture and moisture but particularly to soil salinity. Both devices have distinct spacing between the transmitter and receiver coils $(1 \mathrm{~m}$ for the EM38 and $3.66 \mathrm{~m}$ for the EM31) and a different induction frequency (14.6 kHz for the EM38 and $9.8 \mathrm{kHz}$ for the EM31). This gives each device a different depth of investigation that is approximately 0-2 $\mathrm{m}$ for the EM38 and 0-7 $\mathrm{m}$ for the EM31. Apparent electrical conductivity readings (ECa) were georeferenced by coupling with a GPS (Holux 241). A maximum spacing of $10 \mathrm{~m}$ was maintained between two consecutive measurement points.

Temporal water level variations were monitored in piezometers drilled at the center of the oligosaline pond and close to a neighboring freshwater lake. Water-levels were recorded automatically every four hours using a Schlumberger Mini-Diver ${ }^{\circledR}$ pressure transducer combined with a Baro-Diver ${ }^{\circledR}$ to compensate for atmospheric pressure (both having $\pm 1.5 \mathrm{~mm}$ accuracy).

\section{Geostatistical treatment}

Frequency distributions of EC and ECa were examined and described using summary statistics and normality tests were performed. Samples variograms were developed to describe the spatial structure of the studied variables. Variograms were estimated from the formula:

$$
\gamma(h)=\frac{1}{2 N(h)} \sum_{i=1}^{N(h)}\left(s\left(x_{i}\right)-s\left(x_{i}+h\right)\right)^{2}
$$

(1) where

$N(h)$ is the number of pairs of points and $s\left(x_{i}\right)$ and $s\left(x_{i}+h\right)$ are the values at $x_{i}$ and $x_{i}+h$. The analysis of the variograms was based on their standard characteristics, i.e., range, sill, and nugget effect. A model variogram was fitted to the sample variograms using the least squares method. Finally, ordinary kriging, a geostatistical technique to interpolate the value of a studied variable at an unobserved location, was used to construct maps of the ECa distribution around lakes. For this purpose, Golden Software Surfer 9@ software was used.

\section{Results}

Regional variability in surface water

Figure 3 shows that the first axis of the PCA accounted for $65 \%$ of the total variability in sample sets AQ and TR and that the variable EC was strongly associated with this axis. Thus, the overall amount of dissolved elements was the main variability in the surface water chemistry. The second factorial axis accounted for $21 \%$ of the variance and was associated with high $\mathrm{Ca}^{2+}$ and $\mathrm{Mg}^{2+}$ values in samples with intermediate chemical charge. This aspect of lake water chemistry justified the study of the behavior of the major elements throughout concentration diagrams, and of the regional distribution of the chemical variability using the variable EC.

The main characteristics of water chemistry are presented in Table $2 . \mathrm{Na}^{+}$showed a high coefficient of variation and was strongly associated with EC along the first axis of the PCA. Therefore, concentration diagrams (Fig. 4) were constructed using $\mathrm{Na}^{+}$as a tracer to estimate water concentration factors, assuming its conservative behavior. The unit slope line drawn in Fig. 4 denotes an evolution in proportion to $\mathrm{Na}^{+} . \mathrm{Ca}^{2+}, \mathrm{Mg}^{2+}$, and $\mathrm{K}^{+}$increased in proportion to $\mathrm{Na}^{+}$, particularly for $\mathrm{Na}^{+}$values up to $\sim 510^{-3} \mathrm{~mol} \mathrm{~L}{ }^{-1}$. At higher concentration factors, $\mathrm{Ca}^{2+}$ and $\mathrm{Mg}^{2+}$ 
decreased and $\mathrm{K}^{+}$increased but less than $\mathrm{Na}^{+}$. Among the anions, the alkalinity increased in proportion to $\mathrm{Na}^{+}$for $\mathrm{Na}^{+}$values up to $\sim 510^{-3} \mathrm{~mol} \mathrm{~L}^{-1}$. This kept increasing although less for the $\mathrm{Na}^{+}$values between 5 and $2010^{-3} \mathrm{~mol} \mathrm{~L}^{-1}$, and then increased again in proportion to $\mathrm{Na}^{+}$for higher concentration factors. $\mathrm{Cl}^{-}$and $\mathrm{SO}_{4}{ }^{2-}$ showed a vastly scattered plot at low concentration factors and a trend to increase in proportion to $\mathrm{Na}^{+}$in concentrated waters.

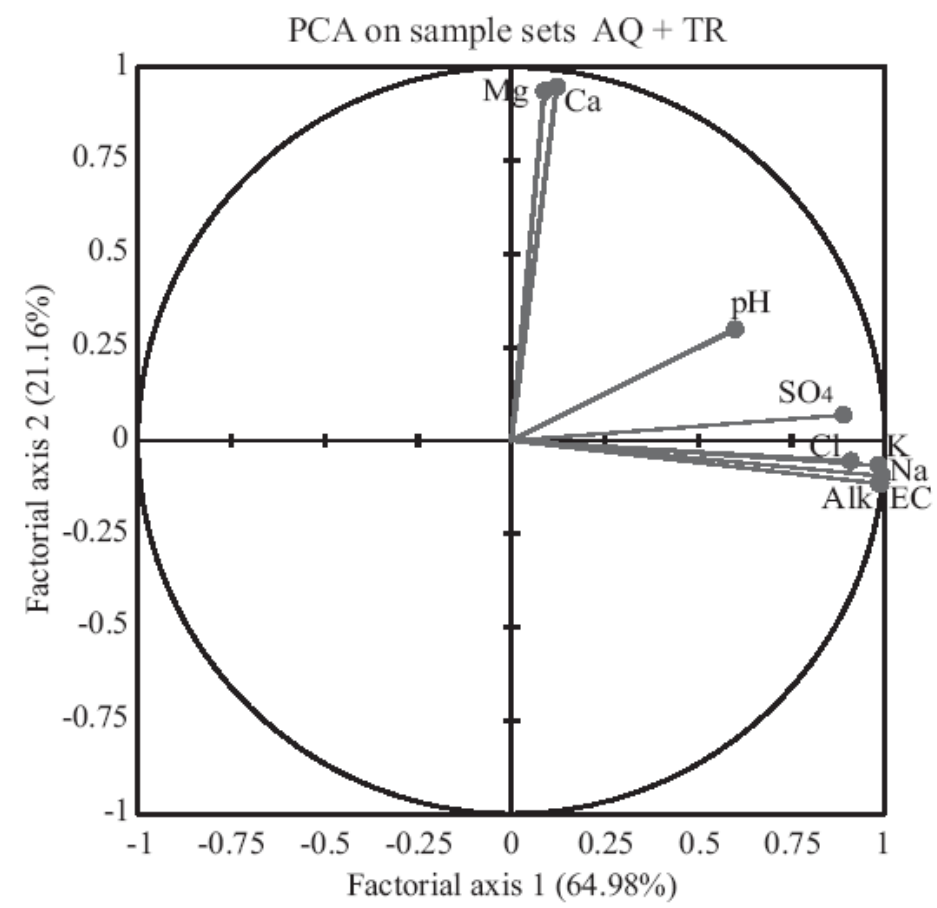

Figure 3 First factorial plan of the PCA carried out on the sample sets AQ and TR.
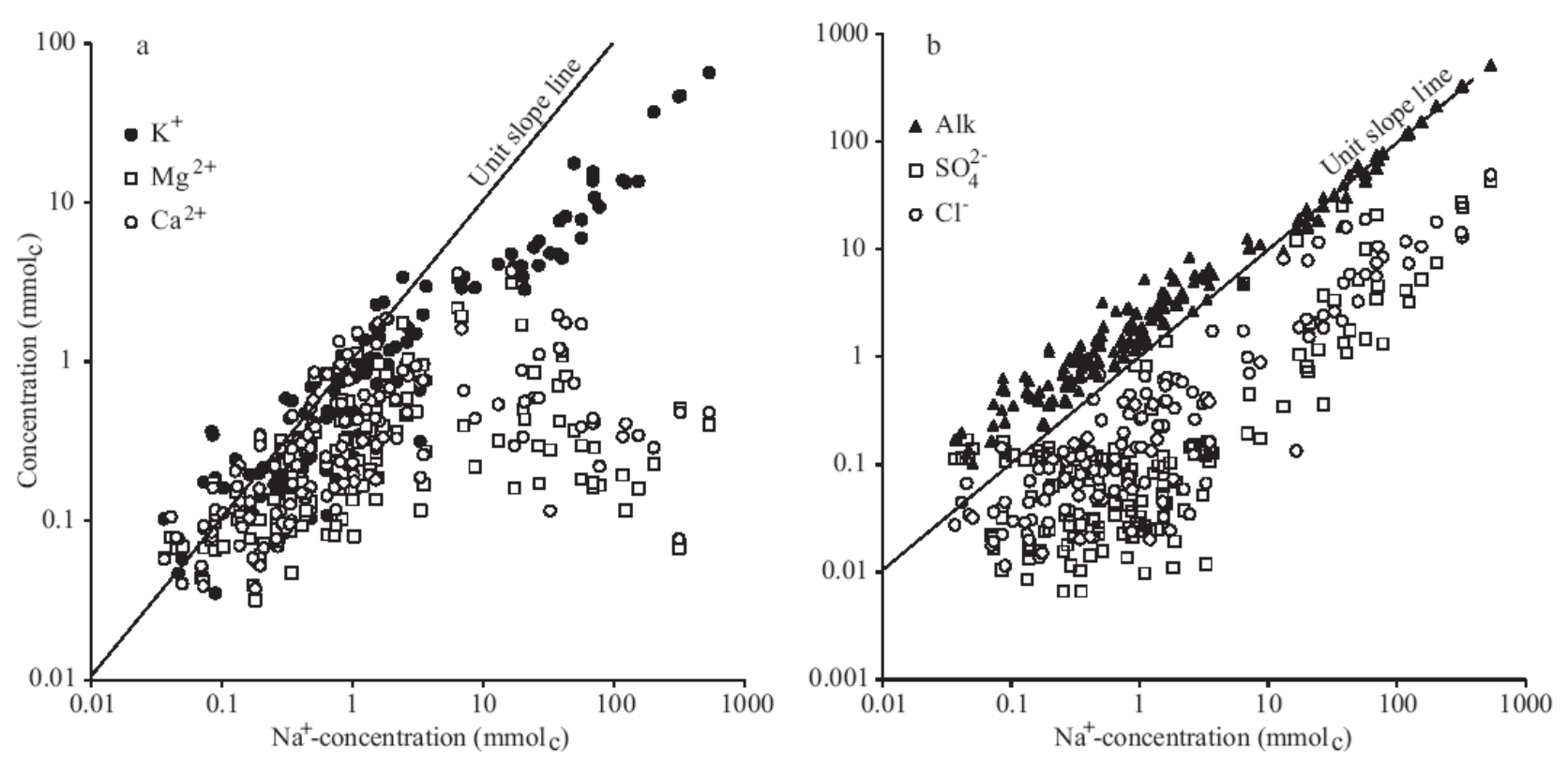

Figure 4 Concentration diagram for (a) major cations and (b) major anions in AQ and TR sample sets.

The EC was wide-ranging, from 16 to $71,400 \mu \mathrm{S} \mathrm{cm}^{-1}$. A histogram of the variable EC, based on the three sample sets (AQ, TR, and $\mathrm{NH}$ ) showed a distribution shifted towards the lowest class of conductivity (0-3000 $\left.\mu \mathrm{S} \mathrm{cm}^{-1}\right)$, which included about $85 \%$ of the samples (Fig. 5a). Therefore, the 
geostatistical treatment was performed on a theoretical distribution of the data by lognormal correction as recommended by Dowd (1983),

$$
z\left(x_{i}\right)=\log _{10}\left(s\left(x_{i}\right)\right)
$$

(2) where

$s\left(x_{i}\right)$ is the EC data at $\mathrm{x}_{\mathrm{i}}, z\left(x_{i}\right)$ is the log-transformed data. The logarithmic transformation of EC into $\log _{10}$ (EC) allowed to better spread out the distribution of the data along the range (Fig. 5b). While a normal distribution was expected, the variable $\log _{10}(\mathrm{EC})$ had a bimodal distribution, with the first mode focused on the value $2.6\left(\mathrm{EC} \sim 400 \mu \mathrm{S} \mathrm{cm}^{-1}\right.$ ) and a second mode on the value 3.8 (EC 6000 $\mu \mathrm{S} \mathrm{cm}^{-1}$ ). A bimodal distribution existed in all sample sets (AQ, TR, and $\mathrm{NH}$ ), considered independently or together. Such a statistical distribution emphasized a deficit of surface water with EC values close to $1500-2000 \mu \mathrm{S} \mathrm{cm}^{-1}$, which will be discussed further below. The $\mathrm{pH}$ showed a good correlation $\left(r^{2}=0.87\right)$ with conductivity (Fig. 6).
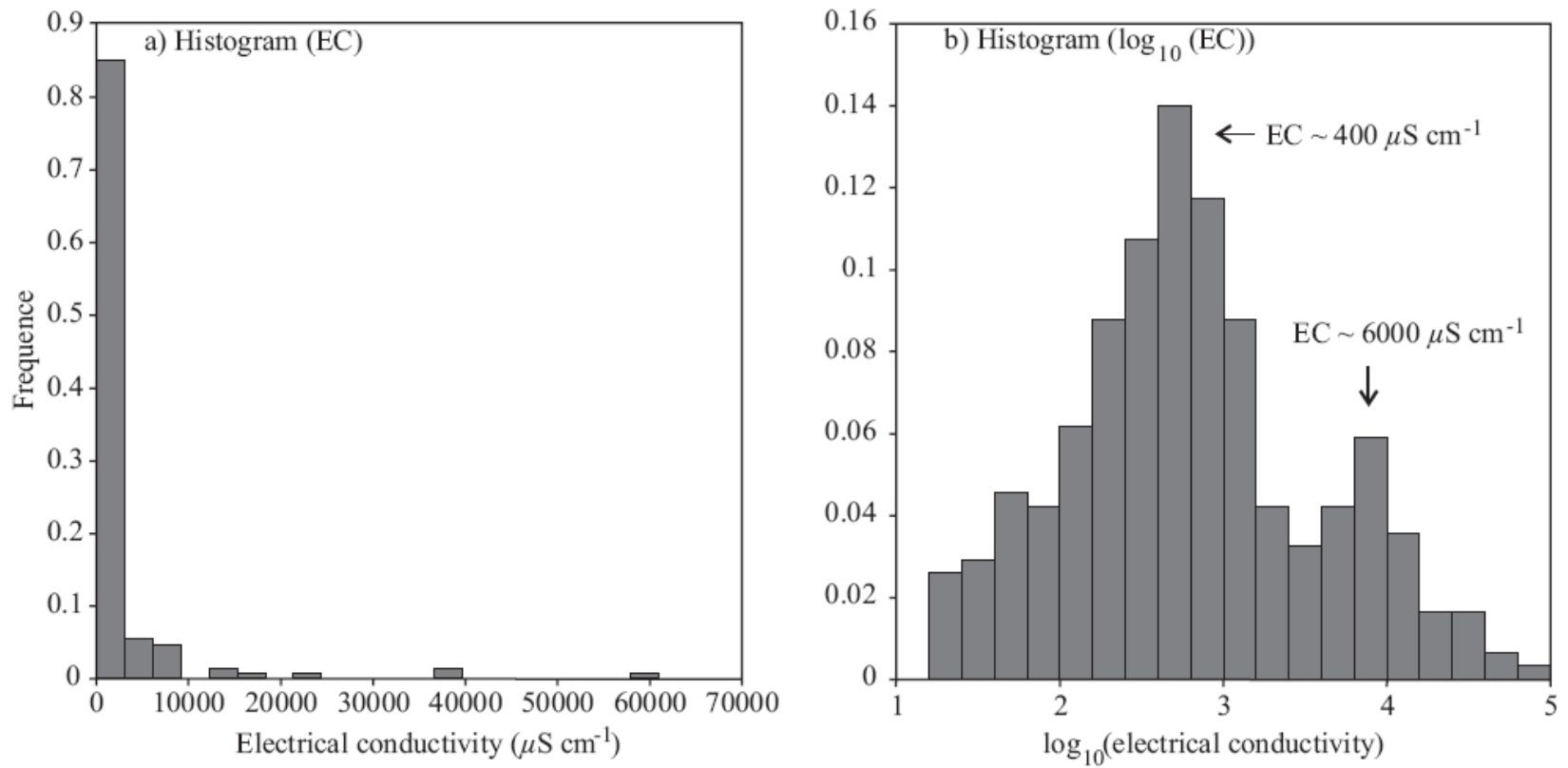

Figure 5 Histogram of (a) the variable EC and (b) of its logarithmic transformation.

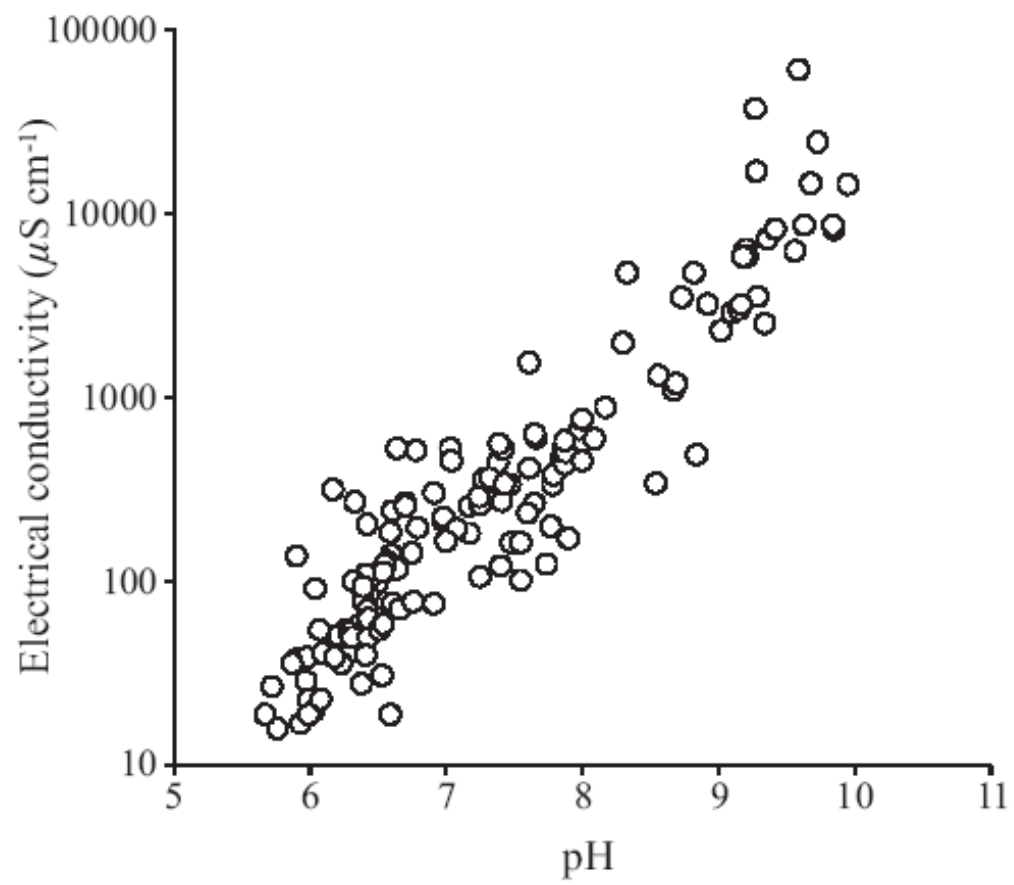

Figure 6 Relationship between $\mathrm{pH}$ and electrical conductivity in surface waters of Nhecolândia. 
The experimental variogram, which describes the structure of spatial variability for the variable $\log _{10}$ (EC), was characterized by a very short spatial range, less than $200 \mathrm{~m}$ (Fig. 7). This suggests that the maximum variability was reached within distances that are smaller than the average distance between neighboring lakes.

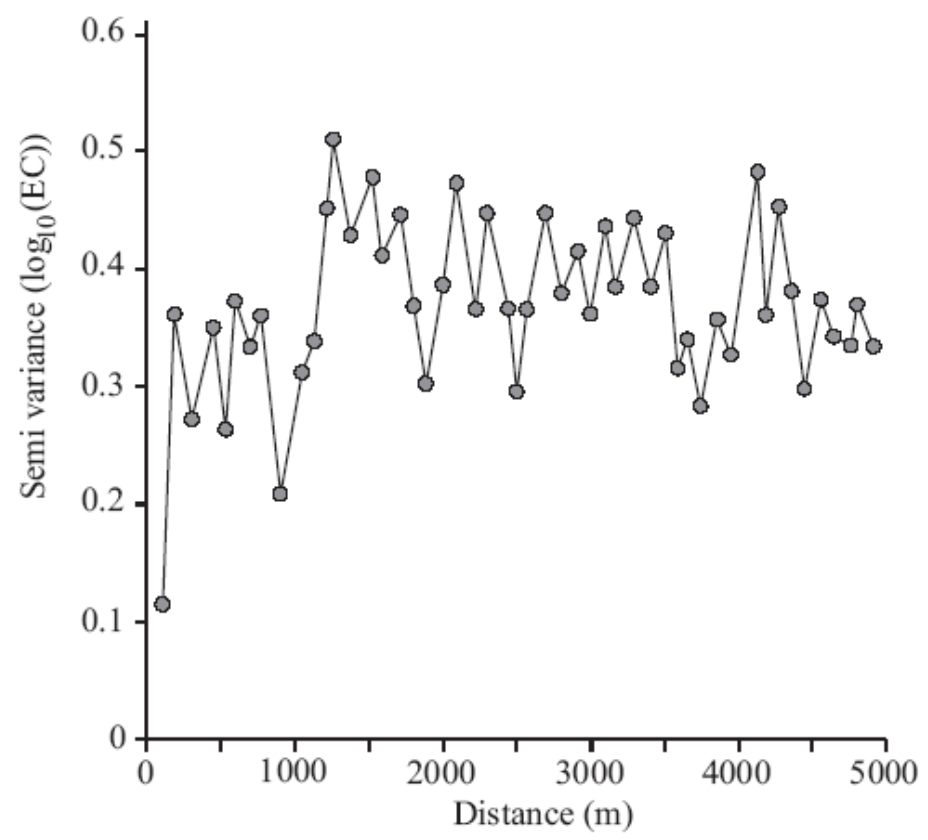

Figure 7 Experimental variogram for $\log _{10}(\mathrm{EC})$ showing high variability within short distance. Note that the sill is reached for distances below $200 \mathrm{~m}$.

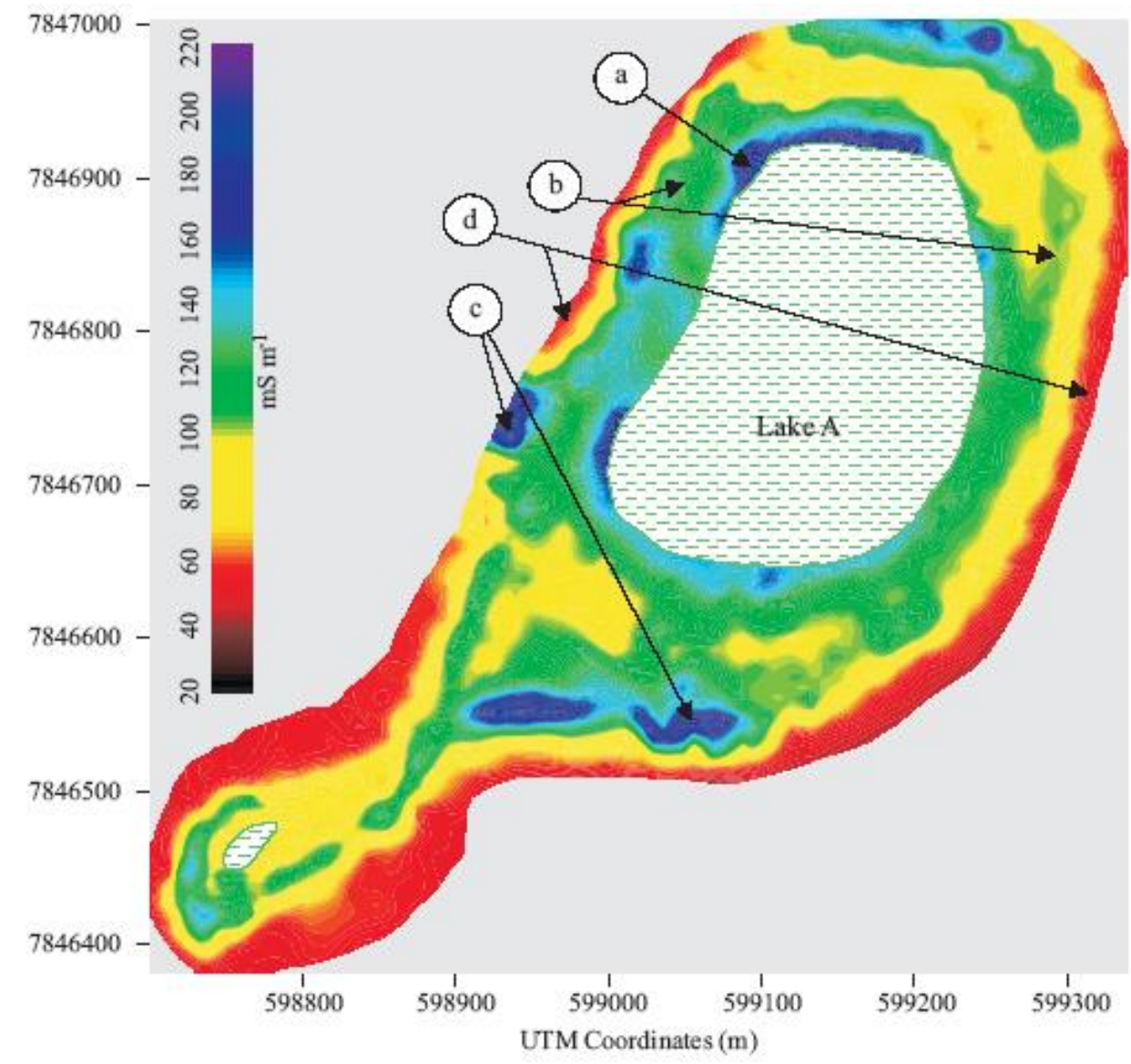

Figure 8 Distribution of ECa values around Lake A from EM38-electromagnetic induction survey. Letters a, b, c, and d denote different sectors in ECa distribution; see text for associated description. 
Soil cover around the lakes

The main statistics for ECa measurements around the saline lakes are given in Table 3. The experimental variograms constructed from ECa values showed similar ranges (approximately $60 \mathrm{~m}$ ) around all the lakes, without a nugget effect. This observation indicated that the $10 \mathrm{~m}$ minimum spacing maintained between successive ECa measurements provided a density of measurements that was sufficient to assess ECa distribution. The ECa maps produced showed similar structures around all of the saline lakes, which can be illustrated using 'Lake A' (Fig. 8). In the immediate vicinity of the lakes there were high ECa values $\left(140-190 \mathrm{mS} \mathrm{m}^{-1}\right)$ that reflected the presence of a clay topsoil, with a maximum thickness of $0.3 \mathrm{~m}$ ('a' in Fig. 8). Surrounding the clay topsoil, slightly farther away from the lakeshore, there was a continuous ring-shaped structure ('b' in Fig. 8) with values in the range of $100-140 \mathrm{mS} \mathrm{m}^{-1}$. Auger surveys showed that this ring-shaped structure corresponded to a rise in subsurface of a green sandy loam horizon (12-20\% clay), being very hard and locally cemented (Fig. 9).
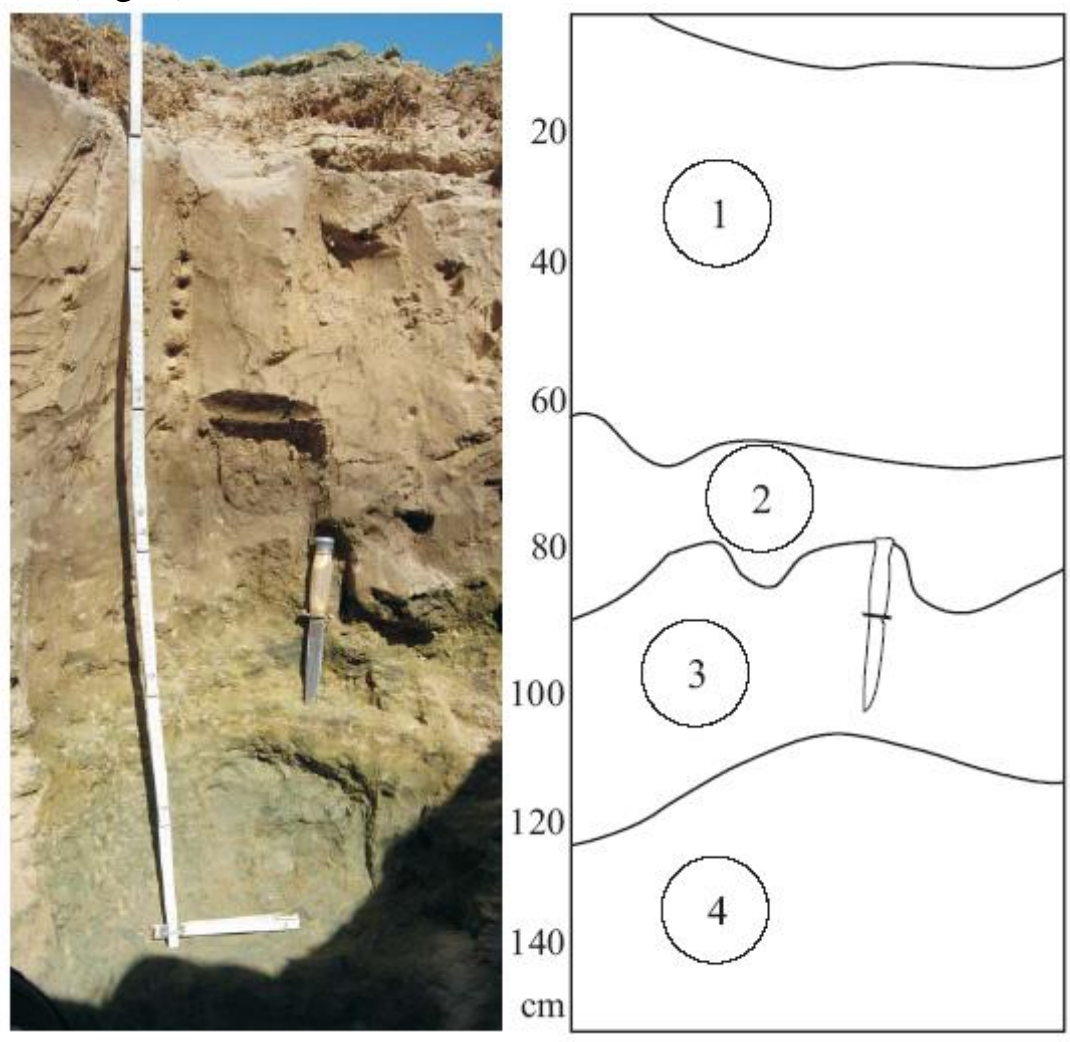

Figure 9 Contact between sandy horizons (1 and 2) and the greenish, hard, and cemented sandy loam horizons (3 and 4).

Just behind, there were discontinuous areas ('c' in Fig. 8) with higher ECa values (in the range of $\left.180-220 \mathrm{mS} \mathrm{m}^{-1}\right)$ that corresponded to the presence of highly saline water $\left(15,000\right.$ to $80,000 \mu \mathrm{S} \mathrm{cm}^{-}$ ${ }^{1}$ ) at approximately $1 \mathrm{~m}$ in depth. Further away from the saline lake, ECa values decreased due to the topographic elevation associated with the thickening of the sandy surface horizon, which became more than $2 \mathrm{~m}$ thick ('d' in Fig. 8). The ECa variations resulted from changes in the deep soil, which were no longer detectable with the EM38 device. In contrast, the EM31 detected a twostage change in ECa values. We first observed a decrease in ECa values, followed by a slight increase at approximately 60-100 $\mathrm{m}$ from the lakeshore, and then a further decline. Direct auger observations showed that the EM31 response (ECa) was a decreasing function of the thickness of the sandy surface horizon (Fig. 10). The increase in ECa between the lakes corresponded to a rise in the greenish sandy loam material, generally approaching $2 \mathrm{~m}$ from the soil surface. The detection of this rise is illustrated in the EM31 survey around 'Lake D', and in cross sections constructed from direct observations around 'Lake D' and between 'Lakes B' and 'Lake C' (Figs. 11,12). Such a rise of 
the greenish material, although less pronounced, was also observed between the oligosaline pond and the freshwater lake nearby. The piezometer monitoring data showed that the groundwater level was always higher in the oligosaline pond than in the freshwater lake, and after each rain event, it stabilized at the top of the green material (Figs. 13,14).

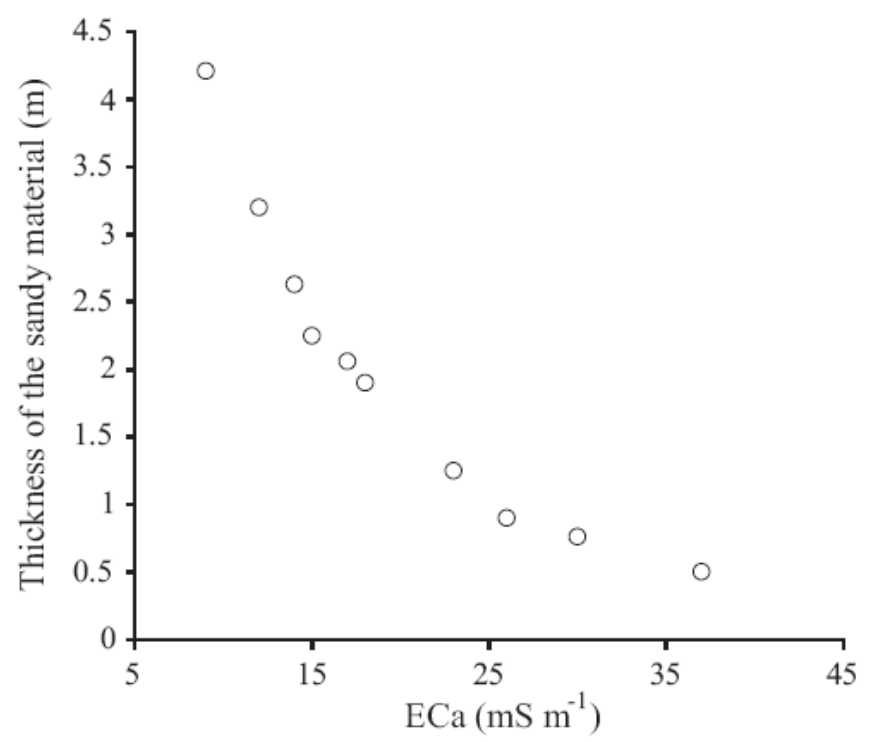

Figure 10 Decreasing relationship between ECa (EM31 device) and the thickness of the sandy material.

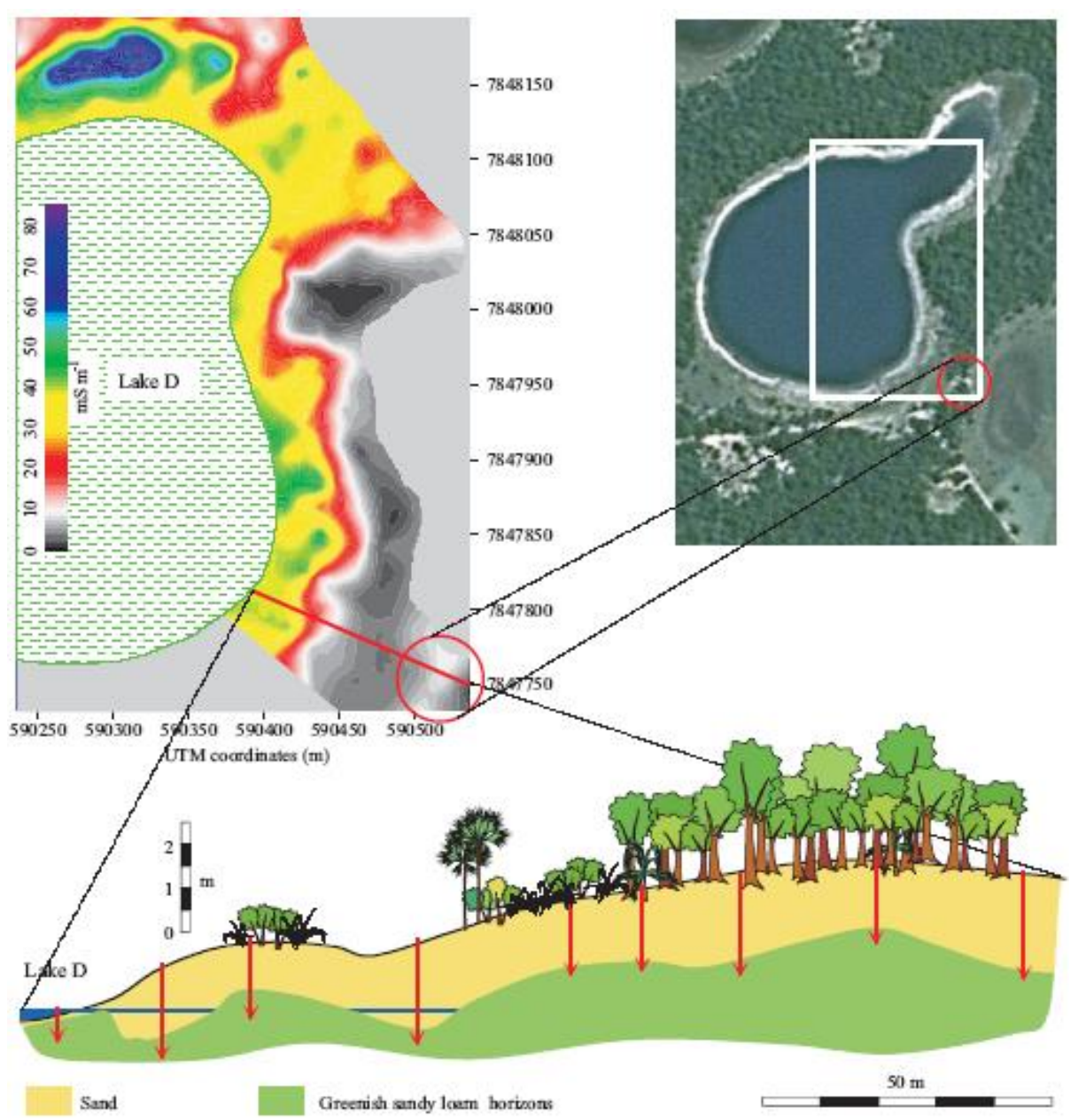

Figure 11 Simplified cross section and EM31-electromagnetic induction survey around Lake D showing a slight increase in ECa values in the higher portion of the forested area at $100 \mathrm{~m}$ from the lake shore (red circle). Red arrows denote auger soil sampling sites. 


\section{Discussion}

Both the regional study of the electrical conductivity of surface water and the local soil survey around the lakes revealed five fundamental points: 1) the existence of a very wide conductivity range, even though climatic conditions do not favor salinization by evaporation. Indeed, the ratio ETP:P is about 1.3 but the excess rainfall from November to March should be sufficient to evacuate the salinity from the landscape; 2) a correlation between $\mathrm{pH}$ and $\mathrm{EC}$ of water; 3) a low range $(<200 \mathrm{~m})$ for the spatial distribution of $\left.\log _{10}(\mathrm{EC}) ; 4\right)$ a bimodal distribution of $\left.\log _{10}(\mathrm{EC}) ; 5\right)$ a standard distribution of ECa values around the lakes, which reflected a standard morphology in the soil cover. These five points will be discussed below.

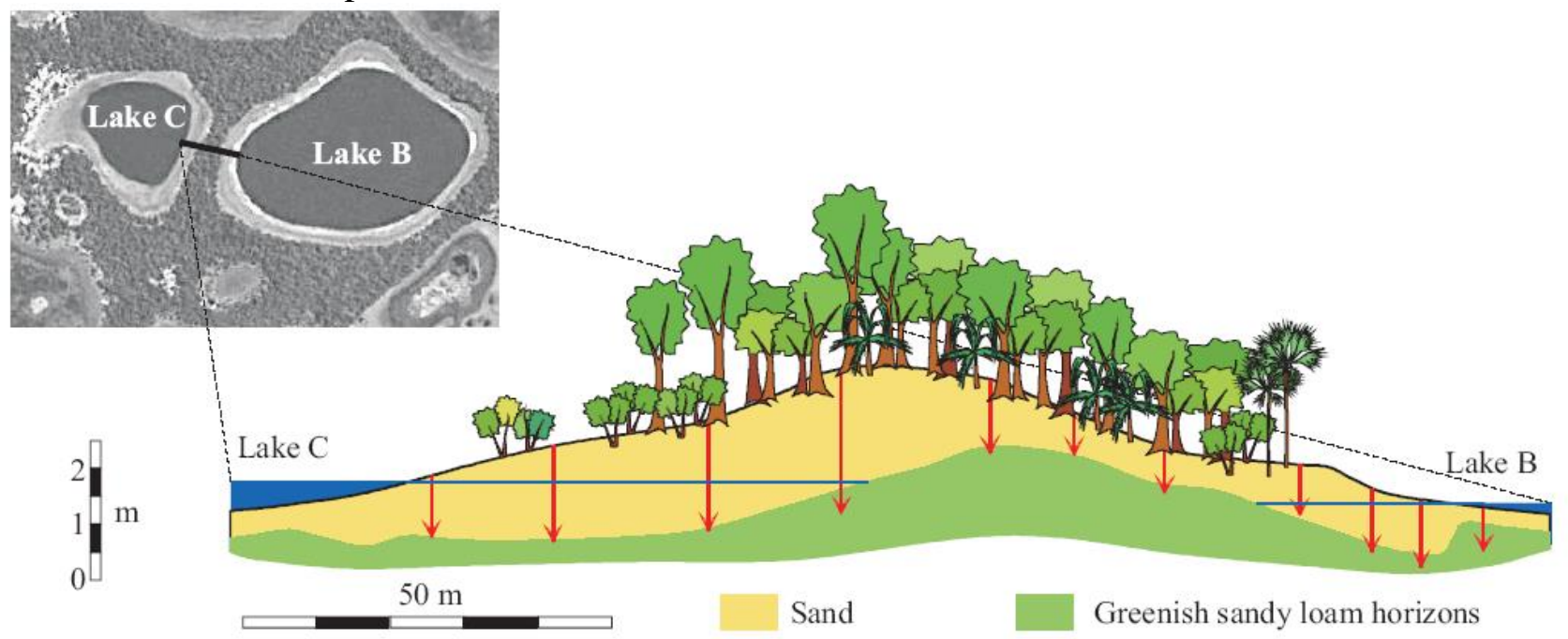

Figure 12 Simplified cross section between Lakes B and C showing the rise of sandy loam greenish horizons with low permeability. Note the difference in water level on both sides of the threshold.

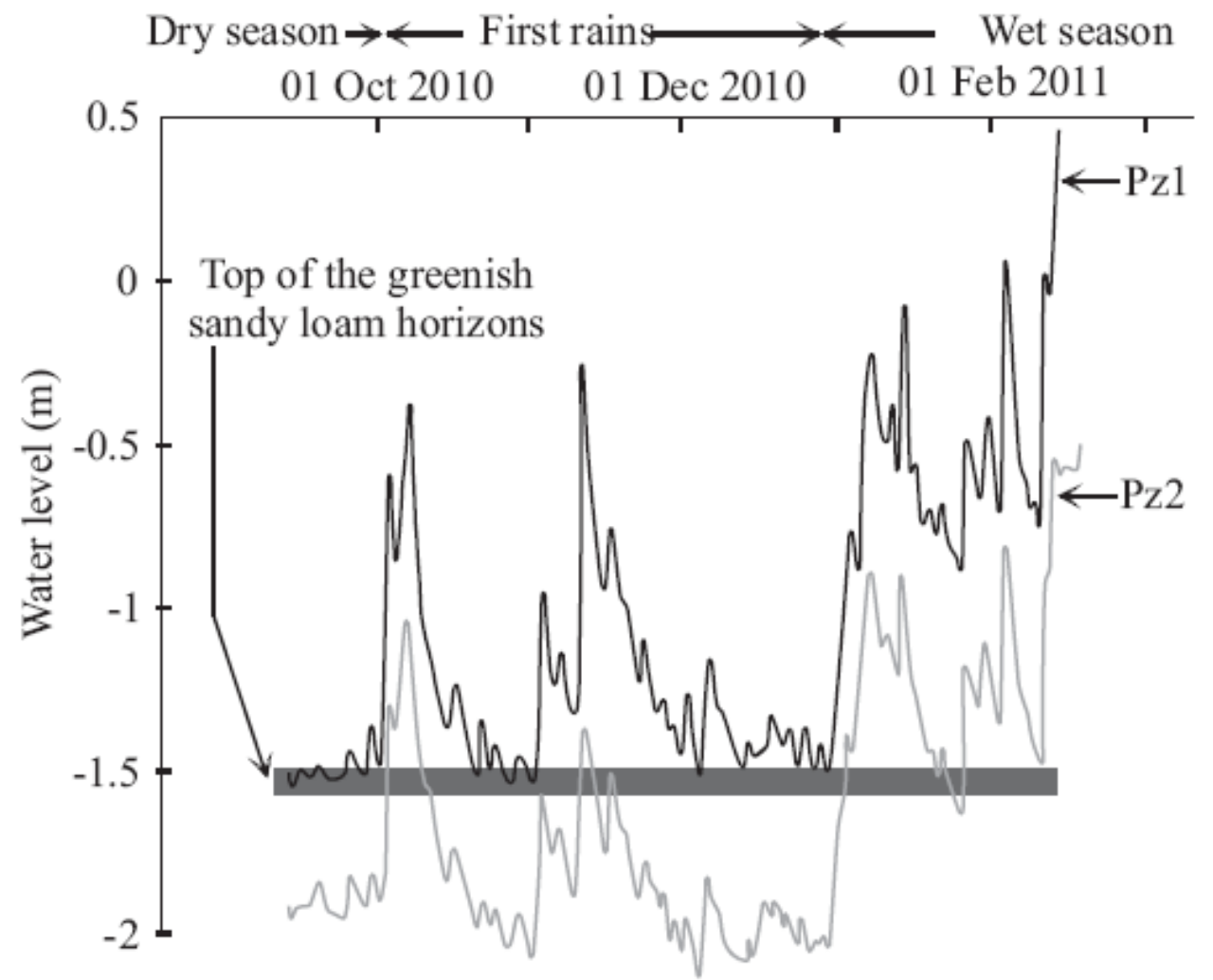

Figure 13 Groundwater level variations and groundwater distribution in wet and dry season between the oligosaline pond and a freshwater lake nearby. Level 0 corresponds to the topsoil at the center of the oligosaline pond (see also Fig. 13 for piezometers Pz1 and Pz2 location) 
The high range in the surface water conductivity may be a reflection of two possible characteristics, including the presence of a salt stock accumulated during earlier arid phases, which would still affect the local water chemistry; or an accumulation of dissolved elements over several years, resulting in saline waters isolated from the current transfers of freshwater across the Pantanal, and therefore sheltered from desalination by circulating waters. The following results make it possible to confirm the second hypothesis.
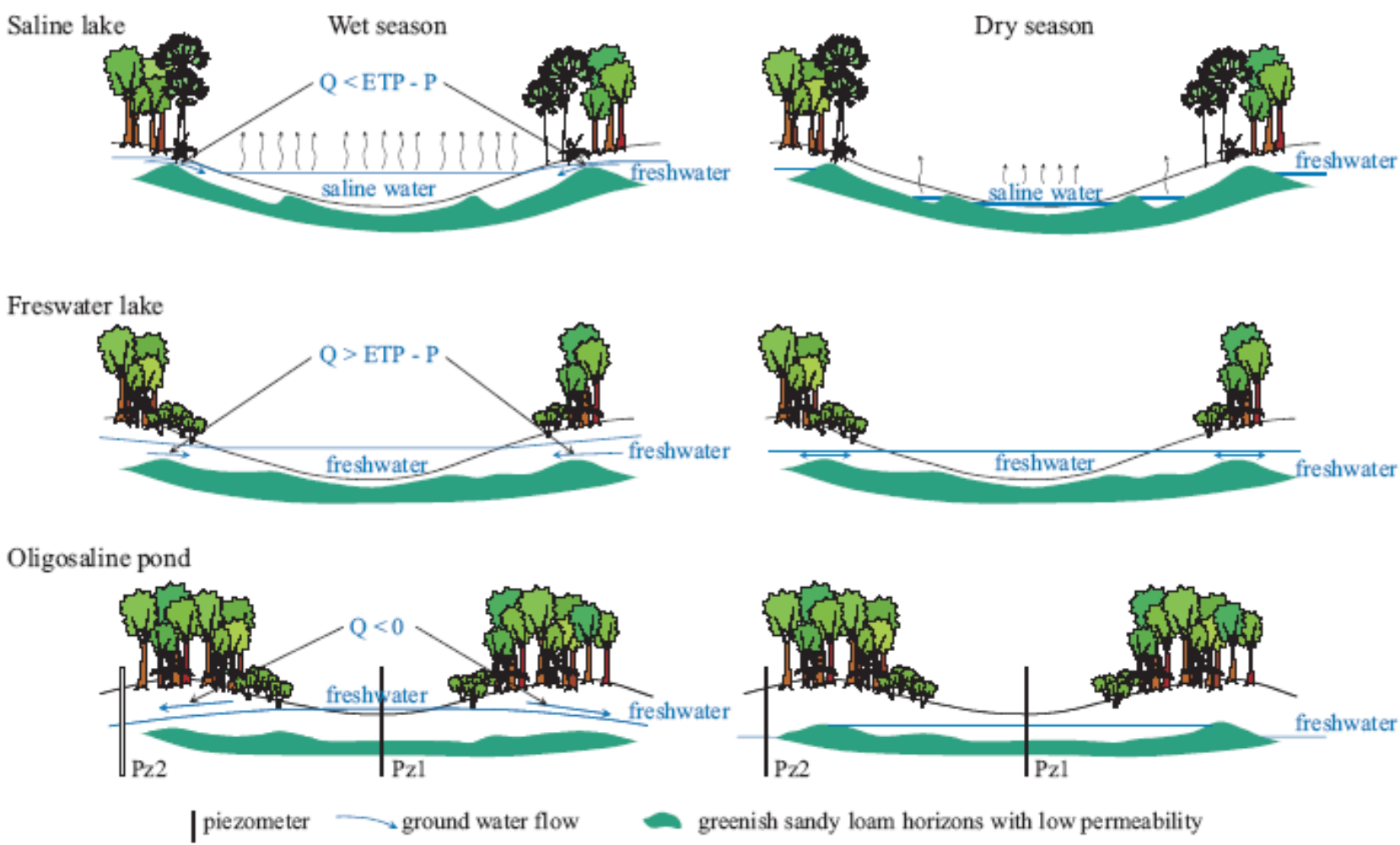

Figure 14 Schematic hydrological functioning of saline lakes, freshwater lakes and oligosaline ponds during wet and dry season. Q denotes the fraction of water flowing towards the lake; $\mathrm{P}$ is the annual precipitation; ETP is the annual evapotranspiration.

The correlation between $\mathrm{pH}$ and EC (Fig. 6) is consistent with previous work carried out on a local scale or on a reduced number of samples. The waters of the region have a positive calcite residual alkalinity ( $\mathrm{RA}_{\text {calcite }}$ ) (Alkalinity $>\mathrm{Ca}^{2+}$ in millimoles of charge $\mathrm{mmol}_{c}$, Droubi et al. 1980) and therefore develop a sodic alkaline pathway under the influence of evaporation (Barbiero et al. 2002, 2004). Such geochemical evolution is frequent in continental arid or semi-arid environments and has been described in all the continents (Barbiero et al. 2008). The concentration is accompanied by an increase in alkalinity, and therefore in $\mathrm{pH}$ that can rapidly reach values close to 10. Several local studies have described saline mineral precipitations associated with evaporation of alkaline waters in Nhecolândia. During the concentration process, the first mineral that forms is a Mg-calcite (with about 5\% Mg), which appears as centimeter-scale nodules, usually associated with Sr- and Ba-carbonates (Barbiero et al. 2008). Then the soil solution reaches saturation with respect to Mg-silicate of stevensite and saponite type (Furquim et al. 2008, 2010a), which precipitate in the upper part of the soil profiles on saline lakeshores (Fig. 8a). Under conditions of positive $\mathrm{RA}_{\text {calcite, }}$ alkalinity increases and the $\mathrm{Ca}^{2+}$ and $\mathrm{Mg}^{2+}$ content decrease. Control of $\mathrm{Ca}^{2+}$ and $\mathrm{Mg}^{2+}$ concentrations in solution are presented in Fig. 4a, but also appear as second axis of variabilty of the PCA (Fig. 3). The last mineral formed is a Fe-illite, which was detected in the fine clay fraction $(<0.2 \mu \mathrm{m})$ of horizons with greenish color in the beach around a saline lake (Furquim et al. 2010b). Fig. 4a shows a control of $\mathrm{K}^{+}$in the most saline waters, suggesting that this element is involved in 
the formation of Fe-illite mineral phase. The above mentioned saline precipitations and clay neoformations have been identified in local studies, but our set of data shows that they have an influence on the chemical composition of surface water at a regional scale. According to RezendeFilho et al. (2012), the scatter plot for $\mathrm{Cl}^{-}$and $\mathrm{SO}_{4}{ }^{2-}$ (Fig. 4b) could be attributed either to local soil transformations involving redox processes or to fertilization pollutants from an extensive agricultural area located upstream on the plateau, which consists mainly of a combination of both $\mathrm{KCl}$ and $\left(\mathrm{NH}_{4}\right)_{2} \mathrm{SO}_{4}$ enriching agents.

Overall, the waters in the region result from simple concentration and dilution of one original source, whose chemical composition is close to that of the Taquari River (Rezende-Filho et al. 2012). The sum of the contribution to the total variance for both factorial axes 1 and 2 (Fig. 3) indicates that evaporation and associated mineral precipitations that control $\mathrm{Ca}^{2+}$ and $\mathrm{Mg}^{2+}$ explain at least $86 \%$ of the chemical variability in surface waters in sample sets AQ and TR.

The spatial range in the distribution of conductivity values of surface waters is less than $200 \mathrm{~m}$, which is typically less than the average distance between two neighboring lakes. Therefore, the salinity levels of neighboring lakes are independent. From this result we conclude that the process that controls the chemical characteristics of surface waters acts in the soil cover between neighboring lakes. The bimodal distribution of salinity provides additional information. It shows that the process controlling the concentration of lake water either guides the water towards high salinity, or conversely towards dilution, which is more in line with the waters that flow regionally in the landscape.

These results confirm that the hydrological functioning of the lakes is controlled locally by a soil system, which is representative of the region. The soil mantle, as demonstrated by the ECa surveys, indicates that the lakes are surrounded by subsurface rises of green sandy loam horizons with low permeability. Such morphology of the soil cover is identical to that described in other parts of Nhecolândia by Sakamoto (1997) and Furquim et al. (2010a) at about $100 \mathrm{~km}$ to the West and $85 \mathrm{~km}$ to the Northwest from the Centenario farm, respectively. The concordance among the ring-shaped structures in the soil system, the presence of lakes, and the mineralogical composition of their clay fraction, emphasize a chemical sedimentation induced by the concentration of the solutions. The genesis of these concentric structures has been previously discussed by Barbiero et al. (2008). Although the clay proportion in the greenish sandy loam horizons is low and therefore conducive to permeability, the presence of high sodium equivalent fraction, in addition to the cementation by silica, radically decreases water infiltration rate at about $1 / 1000$ with respect to the sandy material located above (Barbiero et al. 2007). Thus, contact between the sandy material with the greenish sandy loam horizons governs the water flow (Fig. 14). More specifically, the height of the greenish horizons surrounding a lake in relation to the overlying sand is a factor in controlling movement of water in the subsurface towards the lakes. When the water table is lower than the greenish material, water flow is impaired. When the water table is higher than the greenish material, water can flow more readily in the overlying sand. At the beginning of the wet season, accumulation of rainfall in the Pantanal causes a rise in the water level. Despite this, the flows of water between lakes remain generally in the subsurface zone. When the water level exceeds the upper level of the greenish material, a fraction flows down toward the depressions of the saline and freshwater lakes (Fig. 14). The average quantity of water, 'Q', flowing annually towards the lakes depends on the relative height of the greenish material with respect to the regional freshwater table. This quantity decreases with increasing height of the greenish material acting as hydrological threshold. Two cases may occur: if $\mathrm{Q}<\mathrm{ETP}-\mathrm{P}$, then lake salinity increases. If $\mathrm{Q}>\mathrm{ETP}-\mathrm{P}$, then the lake is flushed every year and the salinity is maintained at a low level. Oligosaline lakes and ponds maintain a very low concentration rate by receiving and redistributing rainwater in the surrounding landscape units with $\mathrm{Q}<0$.

The above-described hydrological organization explains how lakes subject to the equivalent amounts of evaporation and rainfall can have different dissolved ion concentrations. Because it is a cumulative process, it explains the wide range of salinity observed in the region. It also clarifies the bimodal distribution of the electrical conductivity observed in approximately 300 lakes, since long- 
term salinity increases from year to year (saline lakes) or is maintained at a low level (freshwater lakes). The correlation between $\mathrm{pH}$ and EC confirms that the chemistry of all surface water corresponds to the different stages of concentration of the Taquari water under the influence of evaporation. This is done in an alkaline pathway with increasing alkalinity and therefore increasing $\mathrm{pH}$ during evaporation. At least, the very local hydrological control of the salinity explains why the salinity levels of neighboring lakes are independent, as shown from the narrow spatial range for EC $(<200 \mathrm{~m})$ observed on the variogram (Fig. 7).

Here we provide evidence that the hydrochemical functioning and the soil system and its organization, which were described around a single lake in Nhecolândia, can be generalized to the region. Our study also highlights the lack of regional distribution pattern of salinity, and the independence of salinity level even for nearby lakes, which is a consequence of local control of water flow around each lake. The co-existence of both saline and freshwater lakes occurs as a result of the distribution of the soil cover that induces a differential hydrological regime. The saline lakes are partially isolated from the regional fresh groundwater-surface water system, due to the higher elevation of low permeability soil horizons that act as a hydrological threshold. These limit the flux of fresh groundwater into the saline lakes, thereby preventing their dilution. These saline lakes work as discharge-wetlands (Jolly et al. 2008). In contrast, freshwater lakes, with lower threshold elevation, have continuous water cycling, so the effect of evaporation is much less pronounced. They work as flow through-wetlands. Oligosalines lakes and ponds, which lie on higher ground $(0.5 \mathrm{~m})$, are surrounded by a rise of the greenish material, although with low elevation. These wetlands receive and rapidly redistribute rainwater throughout the surrounding landscape units, thus working as recharge-wetlands. The hydrological functioning of lakes in Nhecolandia in relation to controls on salinity is consistent with what has been observed in arid or semi-arid wetlands receiving low and variable annual rainfall and characterized by potential evapotranspiration that is far greater than precipitation (ETP:P $>2$, Jolly et al. 2008). Our study shows that under poor drainage conditions, salinity can maintain naturally in the landscape despite relatively humid mean climatic conditions.

The study adds to our knowledge of how the relation of lakes to subsurface flow (groundwater), and the geological characteristics affecting that flow, is important to understanding the controls on the salinity of lake and wetlands in general. The differential hydrological regime between all these lakes indicates that it is not necessary to resort to former arid environmental conditions to explain the presence of saline waters in some lakes of Nhecolândia. It does not mean that a much drier climate did not occur during the Pleistocene, as recently confirmed by Whitney et al. (2011) from lake sediments in the northern Pantanal, but, the presence of salinity does not provide evidence for such a paleoclimate reconstruction.

However, one issue remains unresolved. Based on Furquim et al. (2010b), we must keep in mind that the greenish material required saline-alkaline conditions for its formation, i.e., for solubilization of silica and neoformation of clays, which are typical of these saline alkaline environments. On the other hand, under present day climatic conditions, saline-alkaline waters need to be isolated from the regional drainage (by the greenish material) to be maintained in the landscape. This chicken or egg situation suggests two hypothesis: the freshwater lakes have worked in the past like the saline lakes do today. It could have occurred under a climate with a more pronounced dry season, perhaps like the climate that prevailed after 19,500 years before present during deglacial warming (Whitney et al. 2011) and more specifically about 5000 years before present (Marchant et al. 2009; McGlue et al. 2012) characterized by a more xeric vegetation compared to present conditions. With these conditions, even a slightly lower water level in Nhecolândia could shift a freshwater lake hydrological regime (flow through-wetland type with Q>ETP-P), to one of a saline lake (discharge-wetland type with Q<ETP-P). Such alteration could have favored a much larger proportion of saline lakes than today; or despite its morphological similarity, the mineralogical composition of the greenish material located at about $100 \mathrm{~m}$ from the lake shore differs from that collected close to the saline lakes and studied by Furquim et al. (2010b). 
In this case, its formation may result from a more regional process not requiring the presence of alkaline water. A specific study of this material should clarify this ambiguity. Future research efforts should also focus on the modeling of the hydrochemical functioning of the lakes in order to test their sensitivity to changes in the local hydrology or in rainfall and evapotranspiration distribution. 


\section{References}

Ab'Saber, A. N. 1988. O Pantanal Mato Grossense e a teoria dos refugios. Revista Brasileira de Geografia 50: 9-57. [The Pantanal of Mato Grosso and the theory of refuges.]

Alho, C. J. R., T. E. Lacher, and H. C. Gonçalves. 1988. Environmental degradation in the Pantanal ecosystem. Bioscience 38: 164-171.

Assine, M. L., and P. C. Soares. 2004. Quaternary of the Pantanal, west-central Brazil. Quat. Int. 114: 23-34, doi:10.1016/S1040-6182(03)00039-9

Barbiero, L., J. P. Queiroz Neto, G. Ciornei, A. Y. Sakamoto, B. Capellari, E. Fernandes, and V. Valles. 2002. Geochemistry of water and ground water in the Nhecolândia, Pantanal of Mato Grosso, Brazil: Variability and associated processes. Wetlands 22: 528-540, doi:10.1672/02775212(2002)022[0528:GOWAGW]2.0.CO;2

Barbiero, L., V. Valles, and C. Cheverry. 2004. Reply to J.W. Van Hoorn 'Some observations with respect to sodicity hazard of irrigation waters'. Agric. Water. Manag. 68: 177-184, doi:10.1016/j.agwat.2004.03.011

Barbiero, L., S. A. C. Furquim, V. Valles, S. Furian, A. Y. Sakamoto, A. T. Rezende-Filho, and M. Fort. 2007. Natural arsenic in groundwater and alkaline lakes at the upper Paraguay Basin, Pantanal, Brazil, p. 101-126. In P. Bhattacharya, A. B. Mukherjee, J. Bundschuh, R. Zevenhoven and R. H. Loeppert [eds.], Arsenic in soil and groundwater environment: Biogeochemical interactions, health effects and remediation: Trace metals and other contaminants in the environment series 9. Elsevier Book Series. doi:10.1016/S18751121(06)09004-3

Barbiero, L., A. T. Rezende-Filho, S. A. C. Furquim, S. Furian, A. Y. Sakamoto, V. Valles, R. C. Graham, M. Fort, R. P. D. Ferreira, and J. P. Queiroz Neto. 2008. Soil morphological control of hydrogeochemistry in a saline and freshwater lake landscape in the Pantanal of Nhecolândia, Brazil. Geoderma 148: 91-106, doi:10.1016/j.geoderma.2008.09.010

Bastviken, D., A. L. Santoro, H. Marotta, L. Q. Pinho, D. F. Calheiros, P. Crill, and A. Enrich-Prast. 2010. Methane emissions from Pantanal, South America, during the low water season: Toward more comprehensive sampling. Environmental Science \& Technology 44: 5450-5455, doi:10.1021/es1005048

Buehler, H. A., G. S. Weissmann, L. A. Scuderi, and A. J. Hartley. 2011. Spatial and temporal evolution of an avulsion on the Taquari River distributive fluvial system from satellite image analysis. Journal of Sedimentary Research 81: 630-640, doi: 10.2110/jsr.2011.040

Dowd, P. A. 1983. Lognormal geostatistics. Science de la Terre, Série Informatique Géologique 18: 49-68.

Droubi, A., B. Fritz, J. Y. Gac, and Y. Tardy. 1980. Generalized residual alkalinity concept application to prediction of the chemical evolution of natural waters by evaporation. Am. J. Sci. 280: $560-572$.

Evans, T. L., and M. Costa. 2013. Landcover classification of the Lower Nhecolândia subregion of the Brazilian Pantanal Wetlands using ALOS/PALSAR, RADARSAT-2 and ENVISAT/ASAR imagery. Remote Sensing of Environment 128: 118-137, doi:10.1016/j.rse.2012.09.022

Fernandes, E. 2007. Organização espacial dos componentes da paisagem da baixa Nhecolândia. Ph.D. thesis Univ. of São Paulo, São Paulo, Brazil. [Spatial organization of the landscape units at the lower Nhecolândia.]

Furquim, S. A. C., R.C. Graham, L. Barbiero, J. P. Queiroz Neto, and V. Valles. 2008. Mineralogy and genesis of smectites in an alkaline-saline environment of Pantanal wetland, Brazil. Clays Clay Min. 56: 580-596, doi:10.1346/CCMN.2008.0560511

Furquim, S. A. C., R.C. Graham, L. Barbiero, J. P. Queiroz Neto, and P. Vidal-Torrado. $2010 a$. Soil mineral genesis and distribution in a saline lake landscape of the Pantanal wetland, Brazil. Geoderma 154: 518-528, doi:10.1016/j.geoderma.2009.03.014

Furquim, S. A. C. , L. Barbiero, R. C. Graham, J. P. Queiroz Neto, R. P. D. Ferreira, and S. Furian, $2010 \mathrm{~b}$. Neoformation of micas in soils surrounding an alkaline-saline lake of Pantanal wetland, Brazil. Geoderma 158: 331-342, doi:10.1016/j.geoderma.2010.05.015 
Fustec, E., and J. C. Lefeuvre. 2000. Fonctions et valeurs des zones humides, Dunod, Paris, France. [Services and values of wetlands.]

Gottgens, J. F., J. E. Perry, R. H. Fortney, J. E. Meyer, M. Benedict, and B. E. Rood. 2001. The Paraguay-Paraná Hidrovía: Protecting the Pantanal with lessons from the past. BioScience 51: 301-308, doi:10.1641/0006-3568(2001)051[0301:TPPHAP]2.0.CO;2

Hamilton, S. K. 1999. Potential effects of a major navigation project (the Paraguay-Paraná Hidrovía) on inundation in the Pantanal floodplains. Regulated Rivers: Research and Management 15: 289-299, doi:10.1002/(SICI)1099-1646(199907/08)15:4<289::AIDRRR520>3.3.CO;2-9

Hamilton, S. K. 2002. Human impacts on hydrology in the Pantanal wetland of South America. Water Science and Technology 45: 35-44.

Humphries, M. S., A. Kindness, W. N. Ellery, J. C. Hughes, J. K. Bond, and K. B. Barnes. 2011. Vegetation influences on groundwater salinity and chemical heterogeneity in a freshwater, recharge floodplain wetland, South Africa. Journal of Hydrology 411: 130-139, doi:10.1016/j.jhydrol.2011.09.041

IBGE, 2003. Base cartográfica integrada digital do Brasil ao milionésimo: versão 1.0 para ArcGis Desktop-ArcView, CD-Rom. IBGE, Rio de Janeiro, Brazil. [Integrated digital cartographic database of Brazil at 1:1,000,000, for ArcGis Desktop-ArcView.]

Jolly, I. D., K. L. McEwan, and K. L. Holland. 2008. A review of groundwater-surface water interactions in arid/semi-arid wetlands and the consequences of salinity for wetland ecology. Ecohydrology 1: 43-58, doi:10.1002/eco.6

Klammer, G. 1982. Die Palaeowuste des Pantanal von Mato Grosso und die pleistozane Klimageschichte des brasilianischen Randtropen. Z. Geomorphol. 26: 393-416. [The palaeodesert of the Pantanal of Mato Grosso and the Pleistocen tropical climate history of the Brazilian border.]

Marchant, R., A. Cleef, S. P. Harrison, H. Hooghiemstra, V. Markgraf, J. van Boxel, T. Ager, L. Almeida, R. Anderson, C. Baied, H. Behling, J. C. Berrio, R. Burbridge, S. Björck, R. Byrne, M. Bush, J. Duivenvoorden, J. Flenley, P. De Oliveira, B. van Gee, K. Graf, W. D. Gosling, S. Harbele, T. van der Hammen, B. Hansen, S. Horn, P. Kuhry, M.-P. Ledru, F. Mayle, B. Leyden, S. Lozano-García, A. M. Melief, P. Moreno, N. T. Moar, A. Prieto, G. van Reenen, M. SalgadoLabouriau, F. Schäbitz, E. J. Schreve-Brinkman, and M. Wille. 2009. Pollen-based biome reconstructions for Latin America at 0, 6000 and 18000 radiocarbon years ago. Clim. Past. 5: 725-767, doi:10.5194/cp-5-725-2009

McCarthy, T. S., J. R. McIver, and B. Verhagen. 1991. Groundwater evolution, chemical sedimentation and carbonate brine formation on an island in the Okavango Delta swamp, Botswana. Appl. Geochem. 6: 577-595.

McGlue, M. M., A. Silva, F. A. Corradini, H. Zani, M. A. Trees, G. S. Ellis, M. Parolin, P. W. Swarzenski, A. S. Cohen, and M. L. Assine. 2011. Limnogeology in Brazil's "forgotten wilderness": A synthesis from the large floodplain lakes of the Pantanal. J. Paleolimnol. 46: 273289, doi:10.1007/s10933-011-9538-5

McGlue, M. M., A. Silva, H. Zani, F. A. Corradini, M. Parolin, E. J. Abel, A. S. Cohen, M. L. Assine, G. S. Ellis, M. A. Trees, S. Kuerten, F. D. Gradella, and G. G. Rasbold. 2012. Lacustrine records of Holocene flood pulse dynamics in the Upper Paraguay River watershed (Pantanal wetlands, Brazil). Quaternary Research 78: 285-294, doi:10.1016/j.yqres.2012.05.015

McNeill, J. D. 1980. Survey interpretation techniques: EM38. Tech. Note TN-6, Geonics Pty.

Mitsch, W. J., and J. G. Gosselink. 2007. Wetlands, 4th ed. John Wiley and Sons.

Oliveira, A. P. G., A. A. Ribeiro, E. R. Wassouf Junior, G. F. Souza, I. Bernardi, N. C. Penatti, T. I. R. Almeida, and A. C. Paranhos Filho. 2011. Uso de Sensoriamento Remoto na quantificação das lagoas do Pantanal da Nhecolândia, Mato Grosso do Sul, p. 3695-3702. In J. C. N. Epiphanio, L. S. Galvão and S. J. dos Campos [eds.], XV Simpósio Brasileiro de Sensoriamento Remoto, INPE. [Use of remote sensing for lakes quantification in the Pantanal of Nhecolândia, South Mato Grosso.] 
Por, F. D. 1995. The Pantanal of Mato Grosso (Brazil). World's largest wetlands. Monographiae Biologicae, vol. 73. Kluwer Academic Publisher.

Pott, V. J., and A. Pott. 2011. Species diversity, distribution and biomass of aquatic macrophytes of the Pantanal, p. 257-280. In W. J. Junk, C. J. da Silva, C. Nunes da Cunha and K. M. Wantzen [eds.], The Pantanal: Ecology, biodiversity and sustainable management of a large neotropical seasonal wetland. Pensoft Publishers.

Quénol, H., L. Barbiero, M. Fort, A. Y. Sakamoto. 2006. Microclimatologie d'une saline dans le Pantanal de la Nhecolândia. Grafigéo 30: 39-42. [Microclimatology of a saline lake in the Pantanal of Nhecolândia]

Reddy, K. R., and R. D. DeLaune. 2008. Biogeochemistry of wetlands: Science and applications. CRC Press.

Rezende-Filho, A. T., S. Furian, R. L. Victoria, C. Mascré, V. Valles, and L. Barbiero. 2012. Hydrochemical variability at the Upper Paraguay Basin and Pantanal wetland. Hydrol. Earth Syst. Sci. 16: 2723-2737, doi:10.5194/hess-16-2723-2012

Sakamoto, A. Y. 1997. Dinâmica hídrica em uma lagoa salina e seu entorno no Pantanal da Nhecolândia: contribuição ao estudo das relações entre o meio físico e a ocupação, Fazenda São Miguel do Firme, MS. Ph.D. thesis Univ. of Sao Paulo, Sao Paulo, Brazil. [Water dynamics in a saline lake and its surroundings in the Pantanal of Nhecolândia: Relationships between the physical environment and occupation.]

Tarifa, J. R. 1986. O sistema climático no Pantanal: Da compreensão do sistema a definição de prioridade de pesquisa climatológica, p. 9-27. In EMBRAPA/DDT [ed.] Anais do Simpósio sobre Recursos Naturais e Socio-econômicos do Pantanal. Brazilian Corporation for Agricultural Research, Brasília. [The climate system in the Pantanal: From understanding of the system to defining climatological research priority.]

Tooth, S., T. S. McCarthy, H. Rodnight, A. Keen-Zebert, M. Rowberry, and D. Brandt. In press. Late Holocene development of a major discontinuity in floodplain wetlands of the Blood River, eastern South Africa. Geomorphology, doi:10.1016/j.geomorph.2011.12.045

Whitney, B. S., F. E. Mayle, S. W. Punyasena, K. A. Fitzpatrick, M. J. Burn, R. Guillen, E. Chavez, D. Mann, R. T. Pennington, and S. E. Metcalfe. 2011. A $45 \mathrm{kyr}$ palaeoclimate record from the lowland interior of tropical South America. Palaeogeogr. Palaeoclimatol. Palaeoecol. 307: 177192, doi:10.1016/j.palaeo.2011.05.012

Zani, H., M. L. Assine, and M. M. McGlue. 2012. Remote sensing analysis of depositional landforms in alluvial settings: Method development and application to the Taquari megafan, Pantanal (Brazil). Geomorphology 161: 82-92, doi:10.1016/j.geomorph.2012.04.003 


\section{Tables}

Table 1 Universal Transverse Mercator (UTM) coordinates (Zone 21K) and electrical conductivity ranges for four selected saline lakes and one oligosaline (Olig.) pond.

\begin{tabular}{lllll}
\hline & \multicolumn{2}{l}{ UTM coordinates in $\mathrm{m}$} & \multicolumn{2}{l}{ EC range $\mu \mathrm{S} \mathrm{cm} \mathrm{cm}^{-1}$} \\
& Longitude & Latitude & \multicolumn{2}{l}{ Sep 2009 to Jul 2011 } \\
& 598915 & 7846624 & 1400 & maximum EC \\
\hline Lake A & 591394 & 7849336 & 2250 & 19473 \\
Lake B & 591165 & 7849306 & 570 & 11470 \\
Lake C & 590459 & 7847808 & 650 & 4750 \\
Lake D & 596860 & 7840426 & 25 & 60400 \\
Olig. pond & & & & 45 \\
\hline
\end{tabular}


Table 2 Descriptive statistics of major elements, $\mathrm{pH}$ and EC in sample sets AQ+TR (147 samples) and AQ+TR+NH (303 samples).

\begin{tabular}{|c|c|c|c|c|c|c|c|c|}
\hline & $\begin{array}{l}\text { Number of } \\
\text { observations }\end{array}$ & Unit & Minimum & Maximum & Mean value & Variance & $\begin{array}{l}\text { Standard } \\
\text { deviation }\end{array}$ & $\begin{array}{l}\text { Coefficient of } \\
\text { variation }\end{array}$ \\
\hline $\mathrm{pH}$ & 303 & - & 5.67 & 10.02 & 7.40 & 1.35 & 1.16 & 0.157 \\
\hline $\mathrm{EC}$ & 303 & $\mu \mathrm{S} \mathrm{cm}^{-1}$ & 16 & 71400 & 2315 & $51.47 \times 10^{6}$ & 7155 & 3.116 \\
\hline $\mathrm{Cl}^{-}$ & 147 & $10^{-3} \mathrm{~mol} \mathrm{~L}^{-1}$ & 0.011 & 49.07 & 1.89 & 28.43 & 5.33 & 2.825 \\
\hline $\mathrm{SO}_{4}^{2-}$ & 147 & $10^{-3} \mathrm{~mol} \mathrm{~L}^{-1}$ & 0.003 & 21.26 & 0.79 & 14.74 & 2.71 & 3.426 \\
\hline Alk. & 147 & $10^{-3} \mathrm{~mol} \mathrm{~L}^{-1}$ & 0.102 & 511.37 & 19.01 & 3798 & 61.63 & 3.243 \\
\hline $\mathrm{Na}^{+}$ & 147 & $10^{-3} \mathrm{~mol} \mathrm{~L}^{-1}$ & 0.036 & 537.59 & 18.63 & 3941 & 62.78 & 3.369 \\
\hline $\mathrm{K}^{+}$ & 147 & $10^{-3} \mathrm{~mol} \mathrm{~L}^{-1}$ & 0.034 & 65.39 & 3.15 & 72.06 & 8.49 & 2.693 \\
\hline $\mathrm{Mg}^{2+}$ & 147 & $10^{-3} \mathrm{~mol} \mathrm{~L}^{-1}$ & 0.016 & 1.56 & 0.18 & 0.09 & 0.22 & 1.198 \\
\hline $\mathrm{Ca}^{2+}$ & 147 & $10^{-3} \mathrm{~mol} \mathrm{~L}^{-1}$ & 0.019 & 1.85 & 0.25 & 0.16 & 0.29 & 1.167 \\
\hline
\end{tabular}


Table 3 Main characteristics of ECa readings using EM31 or EM38 devices around the saline lakes

\begin{tabular}{lllllllll}
\hline & $\begin{array}{l}\text { Device } \\
\text { used }\end{array}$ & Unit & $\begin{array}{l}\text { Number of } \\
\text { observations }\end{array}$ & Minimum & $\begin{array}{l}\text { Mean } \\
\text { value }\end{array}$ & Maximum & $\begin{array}{l}\text { Standard } \\
\text { deviation }\end{array}$ \\
\hline Lake A & EM38 & $\mathrm{mS} \mathrm{m}^{-1}$ & 1589 & 47 & 99 & 245 & 32.9 \\
Lake B & EM31 & $\mathrm{mS} \mathrm{m}^{-1}$ & 2940 & 4.5 & 44.6 & 115 & 23.7 \\
Lake C & EM38 & $\mathrm{mS} \mathrm{m}^{-1}$ & 537 & 54 & 162 & 387 & 44.9 \\
Lake D & EM31 & $\mathrm{mS} \mathrm{m}^{-1}$ & 229 & 11 & 28 & 64 & 11.7 \\
\hline
\end{tabular}

